\title{
PENAMBAHAN EKSTRAK JERUK NIPIS DAN KONSENTRASI INOKULUM TERHADAP KARAKTERISTIK NATA DE SOYA DARI LIMBAH CAIR INDUSTRI TAHU KABUPATEN KLATEN
}

\author{
Syarifah Aini*, Fatkhun Nur \\ Jurusan Teknik Sipil, Fakultas Teknik, Universitas Widya Dharma Klaten, Indonesia \\ *email: aini07931@gmail.com
}

Received 13 November 2019

Accepted 31 December 2019

\begin{abstract}
Abstrak
Melimpahnya Limbah cair tahu (Whey) yang masih mengandung protein dan karbohidrat di kabupaten Klaten akan mengakibatkan pencemaran lingkungan. Sehingga, perlu adanya cara untuk mengolah sumber daya melimpah menjadi produk olahan baru yang memiliki nilai ekonomi cukup tinggi. Maka dilakukannya penelitian pembuatan nata de soya berbahan dasar limbah cair tahu (Whey) dengan menggunakan fermentasi bakteri Acetobacter xylinum dan penambahan ekstrak jeruk nipis. Tujuan penelitian ini adalah untuk mengetahui karakteristik nata de soya dari limbah cair tahu dengan perlakuan penambahan ekstrak jeruk nipis dan konsentrasi inokulum yang berbeda. Metode penelitian ini adalah Rancangan Acak Kelompok terdiri atas dua faktor perlakuan. Faktor pertama yaitu persentase air jeruk nipis $(\mathrm{N})$ yang terdiri dari tiga taraf $(1 \%, 3 \%, 5 \%)$ dan faktor kedua yaitu konsentrasi inokulum (I) yang terdiri dari tiga taraf (5\%, 10\% dan 15\%). Analisis data dilakukan secara statistik, jika terdapat beda nyata dilanjutkan dengan uji jarak berganda Duncan (JBD) pada jenjang nyata 5\%. Hasil penelitian menunjukkan konsentrasi inokulum $5 \%$ dengan jeruk nipis $3 \%$ dan 5\% tidak berpengaruh nyata terhadap tekstur nata de soya. Konsentrasi inokulum $15 \%$ dan jeruk nipis $1 \%$ memberikan nilai terbaik dari semua perlakuan yaitu ketebalan $1,04 \mathrm{~cm}$, rendemen $205,33 \mathrm{~g}$, kadar air $86 \%$, kadar serat $48,6 \%$ dan tekstur 2,48 N.
\end{abstract}

Kata kunci: Limbah cair tahu, Nata de soya, Rancangan acak kelompok

\begin{abstract}
Tofu liquid waste (Whey) which still contains protein and carbohydrates in Klaten district will cause environmental pollution. So, there needs to be a way to process tofu liquid waste into new processed products that have high economic value. So he did research into making Nata de Soya based on tofu liquid waste (Whey) using the fermentation of Acetobacter xylinum and the addition of lime extract. The purpose of this study was to determine the characteristics of Nata de Soya from tofu liquid waste by adding lime extract and different inoculum concentrations. This research method is a Randomized Block Design consisting of two treatment factors. The first factor is the percentage of lime extract $(\mathrm{N})$ consisting of three levels $(1 \%, 3 \%, 5 \%)$ and the second factor is the concentration of inoculum (I) consisting of three levels $(5 \%, 10 \%$ and $15 \%)$. Data analysis was processed statistically, if there were real differences followed by Duncan's multiple range test (JBD) at 5\% real level. The results showed that the concentration of inoculum 5\% with lime extract 3\% and 5\% had no significant effect on the texture of Nata de Soya. The concentration of inoculum $15 \%$ and lime extract $1 \%$ got the best value of all treatments, namely thickness $1.04 \mathrm{~cm}$, rendement $205.33 \mathrm{~g}$, water content $86 \%$, fiber content $48.6 \%$ and texture $2.48 \mathrm{~N}$.
\end{abstract}

Keywords: Tofu liquid waste, Nata de Soya, Randomized block design 


\section{Pendahuluan}

Berdasarkan data Koperasi Tahu Tempe Indonesia Kabupaten Klaten Tahun 2017 menyatakan terdapat 475 perajin tahu dan tempe dengan kebutuhan kedelai mencapai 832 ton setiap bulan. Bahan baku utama pembuatan tahu berupa sari kedelai dengan proses pengendapan protein. Disisi lain, dalam proses pembuatannya menghasilkan beberapa produk samping yang salah satunya berupa limbah cair. Menurut data yang ada, jumlah limbah cair tahu di Kecamatan Jogonalan, Kabupaten Klaten berkisar antara 43,5-45 L untuk tiap kilogram bahan baku kedelai (Hapsari, 2012).

Limbah cair tahu (Whey) masih banyak mengandung bahan organik limbah cair tahu umumnya terdiri atas protein $65 \%$, lemak 25\%, dan karbohidrat 25\% (Hindersah, 2011). Salah satu upayanya yaitu mengolah limbah cair tahu menjadi produk nata dengan memanfaatkan mikrobia Acetobacter xylinum. Salah satu jenis nata yang terbuat dari limbah cair tahu adalah "nata de soya" (Nisa, 2002).

Metabolisme Acetobacter xylinum selama fermentasi dipengaruhi oleh keasaman media. Hal ini disebabkan membran sel bakteri bersifat permeabel terhadap ion hidrogen maupun ion hidroksil, sehingga perubahan keasaman media fermentasi akan mempengaruhi sitoplasma sel bakteri. $\mathrm{pH}$ optimum pembuatan nata berkisar antara 4-5. Penambahan asam asetat berfungsi untuk menurunkan $\mathrm{pH}$ media fermentasi dan digunakan oleh bakteri untuk membentuk asam glukonat. Asam yang digunakan dapat berupa asam sitrat. Sumber asam sitrat salah satunya adalah buah jeruk nipis.

Jeruk nipis mengandung unsur-unsur senyawa kimia yang bermanfaat, seperti linalin asetat, limonene, geranil asetat, sitral, felladren, asam sitrat, asam amino, minyak atsiri, damar, glikosida, asam sitrun, lemak, kalsium, fosfor, besi, belerang vitamin B1 dan C (Lauma dkk.,
2015). Jeruk nipis memiliki kandungan asam sitrat terbanyak diantara jeruk yang lainnya yaitu 7\% (Khotimah, 2002).

\section{Metode Penelitian \\ Alat dan Bahan}

Alat-alat meliputi gelas ukur $100 \mathrm{ml}$ (Pyrex), nampan plastik (Citra), kertas koran, kain saring, panci, kompor. Bahan yang digunakan adalah limbah cair tahu (whey) yang berasal dari sentra industri tahu yang terletak di Desa Bono, Kecamatan Tulung, Kabupaten Klaten, Jawa Tengah, starter Acetobacter xylinum Merk Probiotic Microbial dari Agrotekno Lab Yogyakarta, serta bahan kimia ZA pro analisis dan glukosa (Chemix Lab).

\section{Persiapan Sampel}

Memilih buah jeruk nipis berkualitas baik, tidak cacat dan berukuran seragam. Selanjutnya buah jeruk nipis dicuci bersih kemudian dipotong dan diperas serta disaring untuk diambil esktraknya.

Persiapan sampel dilakukan dengan mengambil limbah cair tahu baru sebanyak $500 \mathrm{~mL}$ untuk masing-masing ulangan kemudian disaring terlebih dahulu. Sterilisasi alat-alat gelas menggunakan autoklaf dan pencucian alat-alat plastik seperti nampan, pengaduk dan panci dicuci sampai bersih, dikeringkan.

\section{Karakterisasi Limbah Cair Tahu}

Sampel diambil berupa limbah cair tahu sebanyak $500 \mathrm{ml}$ menggunakan gelas ukur. Kemudian dilakukan pengamatan fisik air limbah cair tahu, diukur suhu dan $\mathrm{pH}$ limbah cair tahu, diukur kandungan COD, BOD dan total padatan terlarut (TSS) dari limbah cair tahu.

\section{Pembuatan Nata de Soya}

Limbah cair tahu sebanyak $500 \mathrm{ml}$ dididihkan diatas kompor. Limbah cair tahu yang sudah dididihkan kemudian dimasukkan ke dalam wadah yang sudah dibersihkan, kemudian gula dan ekstrak jeruk nipis dicampurkan sesuai taraf 
perlakuan $(1 \%, 3 \%$ dan $5 \%)$ kemudian ditutup dengan kain.

Limbah cair tahu didinginkan sampai suhu ruang kemudian dimasukkan starter sesuai taraf perlakuan yang telah ditentukan $(5 \%, 10 \%$ dan $15 \%)$.

Proses fermentasi dilakukan selama 14 hari pada suhu ruang $29-30^{\circ} \mathrm{C}$, kemudian tempatkan nampan pada tempat yang bersih dan terlindung serta tutupi dengan kertas koran serta diikat menggunakan karet di sekeliling bibir nampan. Kemudian dilakukan analisis fisik dan kimia.

\section{Metode}

Metode penelitiannya adalah Rancangan Acak Kelompok terdiri atas dua faktor perlakuan. Faktor pertama yaitu persentase air jeruk nipis $(\mathrm{N})$ yang terdiri dari tiga taraf $(1 \%, 3 \%, 5 \%)$ dan faktor kedua yaitu konsentrasi inokulum (I) yang terdiri dari tiga taraf $(5 \%, 10 \%$ dan $15 \%)$, yang terdiri atas 3 taraf dan 3 faktor, dengan 3 kali ulangan sehingga banyaknya percobaan yaitu $3 \times 3 \times 3=27$ satuan eksperimental. Data yang diproleh dianalisis keragamannya secara statistik, jika terdapat beda nyata dilanjutkan dengan uji jarak berganda Duncan (JBD) pada jenjang nyata 5\% (Gomez, 1995).

\section{Hasil dan Pembahasan}

\section{Ketebalan Nata de Soya}

Tabel 1 menunjukkan semakin banyak konsentrasi inokulum Acetobacter xylinum yang diberikan akan menambah ketebalan nata, sebaliknya semakin banyak konsentrasi jeruk nipis yang diberikan akan mengurangi ketebalan nata.

Pada Tabel 1, ketebalan nata de soya tertinggi diperoleh dari perlakuan konsentrasi inokulum $15 \%$ dan jeruk nipis $1 \%$ yaitu $1,04 \mathrm{~cm}$ dan ketebalan terendah diperoleh dari perlakuan Inokulum 5\% dan jeruk nipis $5 \%$ yaitu $0,30 \mathrm{~cm}$. Sesuai dengan penelitian Budiarti (2008) yang menyatakan bahwa, ketebalan nata de soya tertinggi diperoleh dari perlakuan konsentrasi inokulum $15 \%$ yaitu setebal
$1,32 \mathrm{~cm}$ dan ketebalan terendah diperoleh dari konsentrasi inokulum 5\% yaitu setebal $0,96 \mathrm{~cm}$.

Peningkatan konsentrasi inokulum menunjukkan ketebalan yang berbeda nyata. Hal ini dikarenakan adanya peningkatan aktivitas bakteri Acetobacter xylinum yang mengubah gula menjadi selulosa dalam media fermentasi limbah cair tahu (Yani dkk., 2000 dan Tamimi dkk., 2015). Selulosa yang terbentuk akan semakin meningkat seiring dengan bertambahnya konsentrasi inokulum Acetobacter xylinum, sehingga akan menghasilkan nata dengan tingkat ketebalan yang lebih tinggi.

Menurut Heryawan (2004) dan Alviani (2016), volume starter/inokulum Acetobacter xylinum yang tinggi dengan nutrisi yang cukup akan meningkatkan kerapatan sel dalam medium fermentasi, sehingga dapat membentuk lapisan selulosa dengan ketebalan beberapa sentimeter. Adanya gula dalam media fermentasi menjadi sumber nutrisi bagi inokulum untuk membentuk selulosa sehingga nata yang dihasilkan menjadi tebal.

Hal tersebut berbanding terbalik dengan perlakuan konsentrasi jeruk nipis. Penambahan konsentrasi jeruk nipis ternyata dapat menurunkan ketebalan nata de soya. Semakin tinggi jumlah konsentrasi jeruk nipis yang ditambahkan dalam media fermentasi limbah cair tahu membuat media menjadi lebih asam yang dapat menurunkan aktivitas Acetobacter xylinum, akibatnya nata yang terbentuk menjadi lebih tipis. Hasil ini sesuai dengan pernyataan Saragih (2004) dan Iryandi, dkk. (2014) yang menyatakan bahwa Acetobacter xylinum dapat tumbuh dan berkembang dalam media asam dengan $\mathrm{pH}$ 3-5 dan optimum pada $\mathrm{pH} \mathrm{4,3.} \mathrm{Saptarina}$ (2017) juga berpendapat bahwa, penurunan $\mathrm{pH}$ media fermentasi (kondisi terlalu asam) juga mengakibatkan oksidasi sukrosa yaitu perubahan gula menjadi asam, sehigga terjadi plasmolisis dalam sel Acetobacter xylinum yang menghambat 
aktivitas pembentukan selulosa, akibatnya lapisan yang terbentuk lebih tipis.

\section{Rendemen Nata de Soya}

Rendemen nata de soya dipengaruhi oleh berat dan ketebalan nata yang diperoleh dari hasil fermentasi. Pada Tabel 2 Rendemen nata de soya semakin meningkat seiring dengan bertambahnya konsentrasi inokulum. Rendemen tertinggi terdapat pada perlakuan konsentrasi inokulum $15 \%$ dengan jeruk nipis $1 \%$, sebaliknya rendemen terendah terdapat pada perlakuan konsentrasi inokulum 5\% dengan jeruk nipis $5 \%$.

Banyaknya rendemen yang dihasilkan berbanding lurus dengan ketebalan nata de soya. Semakin tebal lapisan selulosa nata de soya maka semakin banyak rendemen yang didapatkan. Peningkatan konsentasi inokulum mencapai $15 \%$ memberikan pengaruh yang nyata terhadap rendemen yang dihasilkan. Hal ini sesuai dengan semakin meningkatnya aktivitas bakteri Acetobacter xylinum dan nutrisi yang cukup akan menghasilkan selulosa yang lebih padat, sehingga rendemen yang didapatkan lebih banyak dan lebih tebal.
Menurut Lempang (2006) dalam Saptarina (2017) kondisi lingkungan yang baik dan lama fermentasi juga mempengruhi rendemen nata de soya.

Penambahan konsentrasi jeruk nipis mencapai $5 \%$ juga dapat menurunkan rendemen nata. Media fermentasi yang terlalu asam tidak baik untuk pembentukan selulosa, karena dapat menurunkan aktivitas Acetobacter xylinum. Menurut Nainggolan (2009) dalam Saptarina (2017), Acetobacter xylinum mensintesis sebagian gula menjadi selulosa dan sisanya akan diubah menjadi asam asetat melalui proses pengoksidasian gula, yaitu sukrosa yang akan menurunkan $\mathrm{pH}$ media nata. Apabila Acetobacter xylinum tumbuh dalam media dengan $\mathrm{pH}$ yang sesuai, maka akan menghasilkan jutaan lembar benang selulosa yang membentuk jalinan lembaran putih transparan yang disebut nata. Kondisi media dengan $\mathrm{pH}$ yang terlalu asam mencapai 5\% ternyata dapat menghambat pertumbuhan Acetobacter xylinum, sehingga tidak mampu membentuk selulosa dengan maksimal, akibatnya rendemen nata yang dihasilkan lebih sedikit.

Tabel 1. Ketebalan nata de soya dengan perlakuan penambahan konsentrasi inokulum dan jeruk nipis

\begin{tabular}{lllll}
\hline Perlakuan & Jeruk Nipis & Jeruk Nipis & Jeruk Nipis & Rerata \\
& $\mathrm{N} 1(1 \%)$ & $\mathrm{N} 2(3 \%)$ & $\mathrm{N} 3(5 \%)$ & Ketebalan $(\mathrm{cm})$ \\
\hline Inokulum I1 (5\%) & $0,40^{\mathbf{c}}$ & $0,33^{\mathbf{b}}$ & $0,30^{\mathbf{a}}$ & 0,34 \\
Inokulum I2 (10\%) & $0,66^{\mathbf{f}}$ & $0,52^{\mathbf{e}}$ & $0,47^{\mathbf{d}}$ & 0,55 \\
Inokulum I3 (15\%) & $1,04^{\mathbf{i}}$ & $0,97^{\mathbf{h}}$ & $0,86^{\mathbf{g}}$ & 0,96 \\
Rerata Ketebalan $(\mathrm{cm})$ & $0,7^{\mathbf{n}}$ & 0,61 & 0,54 & \\
\hline
\end{tabular}

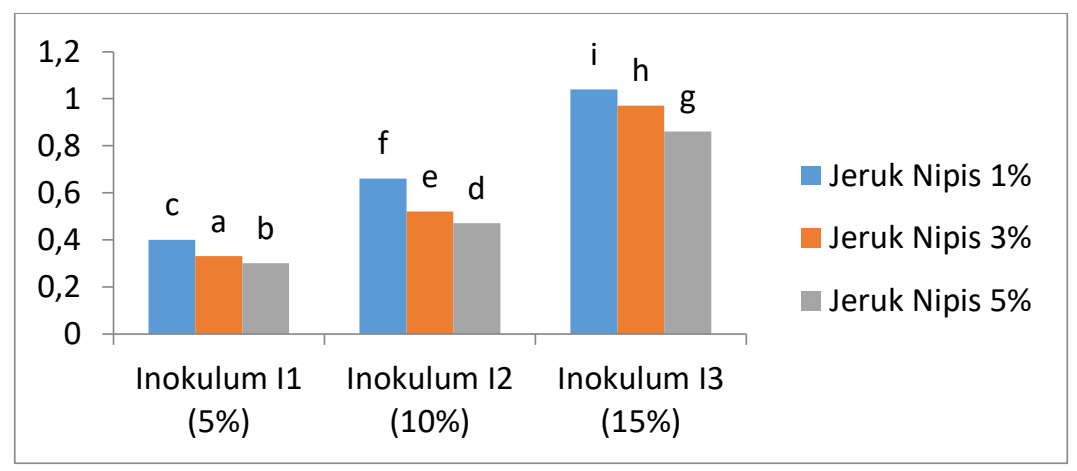

Gambar 1. Grafik ketebalan nata de soya dengan perlakuan penambahan konsentrasi inokulum dan jeruk nipis 
Tabel 2. Rendemen nata de soya dengan perlakuan penambahan konsentrasi inokulum dan jeruk nipis

\begin{tabular}{lllll}
\hline Perlakuan & $\begin{array}{l}\text { Jeruk Nipis } \\
\mathrm{N} 1(1 \%)\end{array}$ & $\begin{array}{l}\text { Jeruk Nipis } \\
\mathrm{N} 2(3 \%)\end{array}$ & $\begin{array}{l}\text { Jeruk Nipis } \\
\mathrm{N} 3(5 \%)\end{array}$ & $\begin{array}{l}\text { Rerata } \\
\text { Rendemen }(\mathrm{g})\end{array}$ \\
\hline Inokulum I1 (5\%) & $78,67^{\mathbf{c}}$ & $73,00^{\mathbf{b}}$ & $58,00^{\mathbf{a}}$ & 69,89 \\
\hline Inokulum I2 (10\%) & $124,60^{\mathbf{f}}$ & $102,00^{\mathbf{e}}$ & $86,00^{\mathbf{d}}$ & 104,20 \\
\hline Inokulum I3 (15\%) & $205,33^{\mathbf{i}}$ & $190,30^{\mathbf{h}}$ & $178,67^{\mathbf{g}}$ & 191,43 \\
\hline Rerata Rendemen $(\mathrm{g})$ & 136,20 & $121,77^{\circ}$ & 107,56 & \\
\hline
\end{tabular}

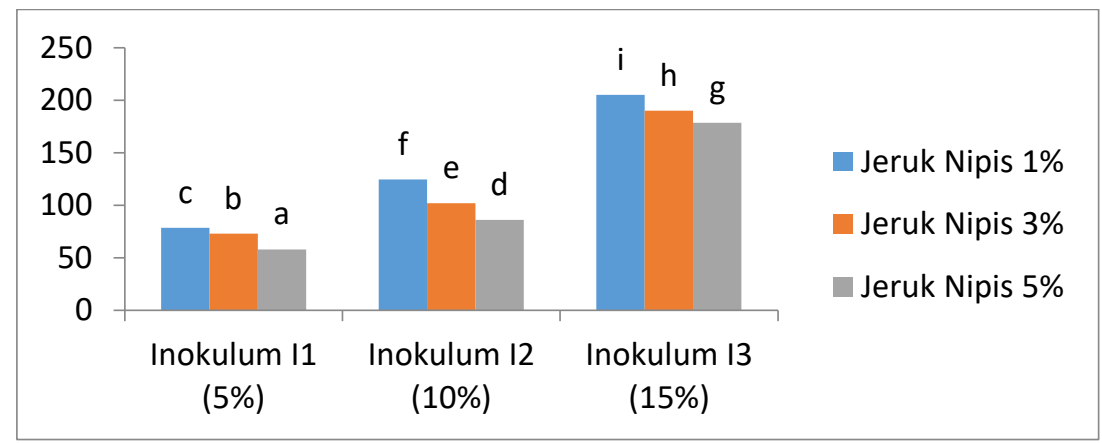

Gambar 2. Grafik rendemen nata de soya dengan perlakuan penambahan konsentrasi inokulum dan jeruk nipis

\section{Kadar Air Nata de Soya}

Pada Tabel 3, peningkatan konsentrasi inokulum berpengaruh nyata terhadap kadar air nata de soya. Kadar air terendah diperoleh pada perlakuan konsentrasi inokulum $15 \%$ dengan jeruk nipis $1 \%$ sebesar $86 \%$, sedangkan kadar air tertinggi pada konsentasri inokulum 5\% dengan jeruk nipis 5\% sebesar 98,3\%. Jumlah air yang terkandung dalam nata de soya dengan konsentrasi inokulum 15\% memberikan nilai yang lebih rendah daripada konsentrasi inokulum 5\%, karena ikatan selulosanya lebih kuat dan rapat yang menyebabkan air tidak banyak terperangkap ke dalam ikatan tersebut. Menurut Iryandi, dkk. (2014), ikatan antar selulosa yang lebih kuat akibat tingginya aktivitas Acetobacter xylinum menyebabkan air yang terikat pada suatu media fermentasi lebih sedikit atau lemah. Hal ini diperkuat juga dengan pendapat Heryawan (2004) dan Alviani (2016), yaitu kemampuan Acetobacter xylinum dalam mengkonversi gula dengan baik menyebabkan air dalam media fermentasi berkurang, bahkan terkadang media fermentasi menjadi kering.

Hal tersebut berbanding terbalik dengan perlakuan peningkatan konsentrasi jeruk nipis. Peningkatan konsentrasi jeruk nipis 3\% dan 5\% tidak memberikan pengaruh yang nyata terhadap kadar air nata de soya, sedangkan pada konsentrasi jeruk nipis $1 \%$ memberikan pengaruh yang nyata terhadap kadar air nata de soya. Namun, jumlah kadar air nata de soya meningkat seiring dengan meningkatnya konsentrasi jeruk nipis. Konsentrasi jeruk nipis sebanyak 5\% memberikan nilai kadar air tertinggi. Hal ini dikarenakan media fermentasi yang terlalu asam $(\mathrm{pH}$ yang sangat rendah) dapat melemahkan ikatan selulosa, sehingga selulosa yang terbentuk kurang rapat dan menyebabkan air mudah terperangkap. Banyaknya jumlah air yang terperangkap mengakibatkan kadar air nata de soya menjadi lebih tinggi. Iryandi, dkk. (2014), berpendapat bahwa air yang terkandung di dalam nata lebih banyak dimana cairan ini terikat ketika struktur nata terbentuk dalam media fermentasi yang sebagian besar komponennya adalah 
air. Air akan banyak terperangkap akibat ikatan antar selulosa yang kurang kuat. Pendapat tersebut diperkuat juga oleh Haryadi (2009), yang menyatakan bahwa media fermentasi yang terlalu asam akan menyebabkan lambatnya pembentukan selulosa oleh karena adanya tekanan osmosis yang tinggi dan menyebabkan sel Acetobacter xylinum mudah mengalami lisis, sehingga pembentukan selulosa tidak optimal.

\section{Kadar Serat Nata de Soya}

Banyak sedikitnya selulosa yang terbentuk tidak hanya berpengaruh terhadap ketebalan dan rendemen nata de soya, tetapi juga berpengaruh pada kadar seratnya. Pada Tabel 4, Kadar serat tertinggi diperoleh dari perlakuan konsentrasi inokulum $15 \%$ dengan jeruk nipis $1 \%$ sebanyak 48,6\%; sedangkan kadar serat terendah diperoleh dari perlakuan konsentrasi inokulum 5\% dengan jeruk nipis 5\% sebanyak 20,3\%.

Persentase serat yang tinggi pada konsentrasi inokulum 15\% dipengaruhi oleh tingginya aktivitas Acetobacter xylinum pada proses metabolisme glukosa menjadi selulosa. Tingginya aktivitas tersebut memberikan dampak yang signifikan, sehingga selulosa yang terbentuk dalam media cair limbah tahu menjadi lebih banyak dan meningkatkan kadar serat nata de soya. Dalam penelitian Alviani (2016), menyatakan bahwa konsentrasi inokulum $10 \%$ dan $15 \%$ mampu memanfaatkan sumber karbon yaitu gula pasir sebagai nutrisinya dengan maksimal, sehingga serat yang dihasilkan semakin tinggi. Hal ini sesuai dengan artikel Pusat Penelitian IPB (2005), yang menyatakan bahwa Acetobacter xylinum menghasilkan selulosa sebagai produk metabolit sekunder, sedangkan asam asetat sebagai produk metabolit primer. Semakin banyak jumlah inokulum yang ditambahkan ke dalam media limbah cair tahu dengan nutrisi yang cukup, maka semakin mudah bakteri tersebut berkembang dan selulosa yang terbentuk mejadi lebih banyak. Selulosa membentuk serat-serat yang berwarna putih, bersifat tidak larut dalam air dan pelarut organik. Semakin banyak selulosa yang terbentuk maka serat yang dihasilkan semakin kuat, lebih tahan terhadap pengaruh kimia, cahaya dan mikroorganisme.

Konsentrasi inokulum 5\% memberikan kadar serat yang rendah begitu juga dengan peningkatan konsentrasi jeruk nipis. Semakin banyak konsentrasi jeruk nipis yang ditambahkan, maka semakin rendah nilai kadar serat nata de soya. Kondisi media fermentasi limbah cair tahu yang terlalu asam atau berada dibawah netral mengakibatkan pertumbuhan Acetobacter xylinum menjadi terhambat, dan mengakibatkan selulosa yang terbentuk tidak optimal, artinya serat-serat yang terbentuk menjadi lebih rendah. Menurut Souisa, dkk. (2007), dalam media fermentasi dengan $\mathrm{pH}$ optimal dapat meningkatkan pertumbuhan bakteri Acetobacter xylinum, sehingga bakteri tersebut mampu membentuk sel-sel baru yang dapat meningkatkan kadar selulosa dan serat nata. Sementara $\mathrm{pH}$ media fermentasi yang terlalu asam kurang baik untuk pertumbuhan dan perkembangan bakteri Acetobacter xylinum.

\section{Tekstur Nata de Soya}

Tekstur nata de soya berkaitan erat dengan kerapatan jaringan selulosa oleh tingginya aktivitas bakteri Acetobacter xylinum dan jumlah kadar air yang terkandung dalam nata. Semakin rendah jumlah kadar air yang terkandung dalam nata, tekstur yang dihasilkan akan lebih keras dan kenyal.

Pada Tabel 5, Peningkatan konsentrasi inokulum berpengaruh nyata terhadap tekstur nata de soya yang diperoleh dengan perlakuan konsentrasi inokulum $15 \%$ dan jeruk nipis $1 \%$, namun tidak berbeda nyata dengan konsentasi jeruk nipis 3\% dan 5\%. Tekstur tertinggi diperoleh dari perlakuan konsentrasi inokulum $15 \%$ dan jeruk nipis $1 \%$ sebesar 2,48 N, sedangkan tekstur terendah 
diperoleh dari perlakuan konsentrasi inokulum 5\% dan jeruk nipis 5\% sebesar $1,73 \mathrm{~N}$. Tingginya tekstur nata de soya dipengaruhi oleh terbentuknya kerapatan jaringan selulosa dengan tersedianya nutrisi yang cukup, sehingga tekstur yang dihasilkan lebih padat dan baik. Hal ini sependapat dengan Tamimi, dkk. (2015) yang menyatakan bahwa, tekstur sangat berkaitan dengan kerapatan jaringan selulosa yang terbentuk dalam media fermentasi, semakin rapat jaringan selulosa maka nata yang dihasilkan akan memiliki tekstur yang baik dan kenyal. Pendapat Effendi (2006) dalam penelitian Alviani (2016) juga menyatakan bahwa, perbandingan antara serat dan kekenyalan berbanding lurus, semakin banyak kandungan serat nata maka teksturnya akan semakin kenyal.
Peningkatan konsentrasi jeruk nipis nencapai 5\% memberikan tekstur nata de soya yang lebih rendah. Menurut Nisa, dkk. (2001) dalam Tamimi, dkk. (2015) konsentrasi asam yang terlalu banyak diduga dapat menghambat aktivitas Acetobacter xylinum dalam membentuk selulosa sehingga, terkstur yang terbentuk menjadi lemah. Nilai tekstur nata de soya juga sangat dipengaruhi oleh kadar air. Kondisi media yang sangat asam akan meningkatkan kadar air nata de soya dan tekstur yang dihasilkan menjadi lunak. Hal ini sesuai dengan pendapat Rahman (2004) dalam Tamimi, dkk. (2015) bahwa struktur kimia dan fisik merupakan efek dari susunan air yang terserap dan berpengaruh besar terhadap tekstur produk yang dihasilkan.

Tabel 3. Kadar air nata de soya dengan perlakuan penambahan konsentrasi inokulum dan jeruk nipis

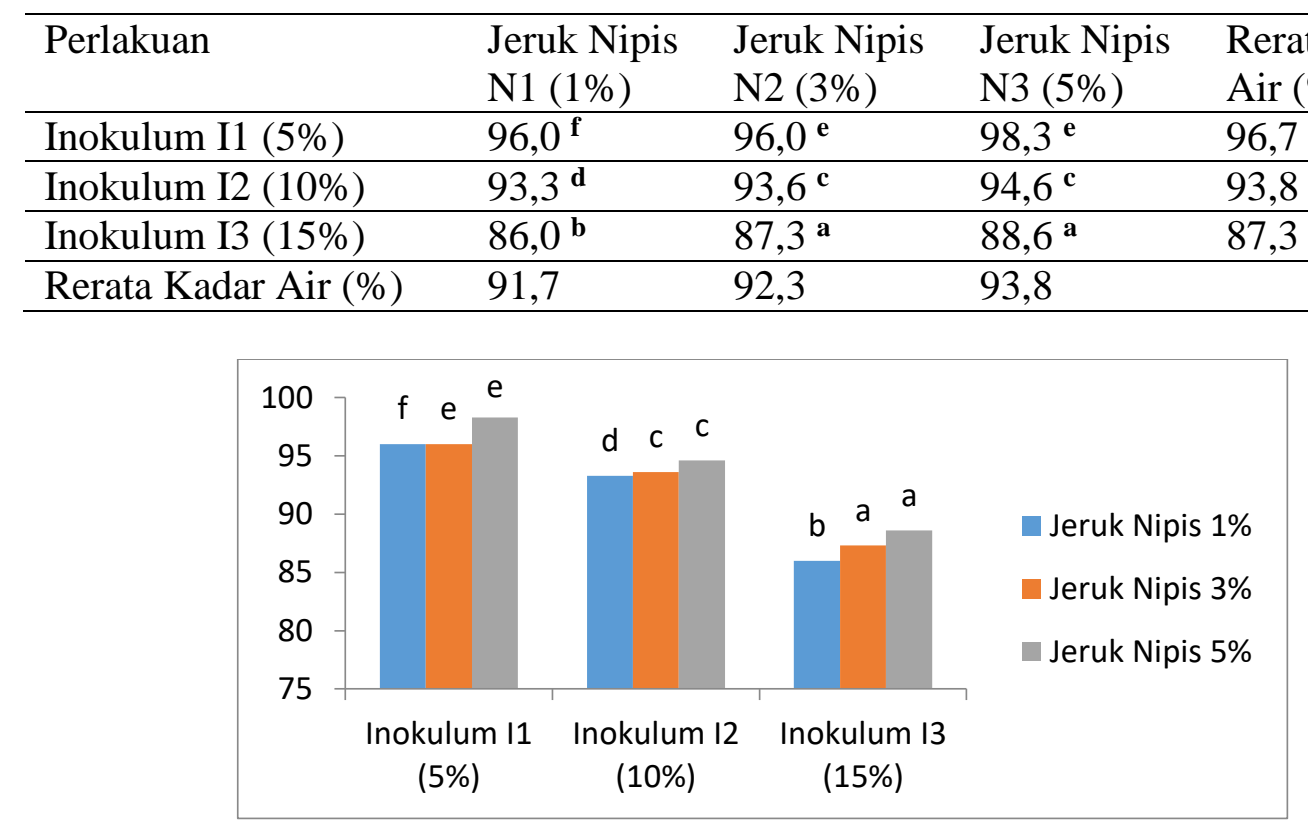

Gambar 3. Grafik kadar air nata de soya dengan perlakuan penambahan konsentrasi inokulum dan jeruk nipis 
Tabel 4. Kadar serat nata de soya dengan perlakuan penambahan konsentrasi inokulum dan jeruk nipis

\begin{tabular}{lllll}
\hline Perlakuan & $\begin{array}{l}\text { Jeruk Nipis } \\
\mathrm{N} 1(1 \%)\end{array}$ & $\begin{array}{l}\text { Jeruk Nipis } \\
\mathrm{N} 2(3 \%)\end{array}$ & $\begin{array}{l}\text { Jeruk Nipis } \\
\mathrm{N} 3(5 \%)\end{array}$ & $\begin{array}{l}\text { Rerata Kadar } \\
\text { Serat }(\%)\end{array}$ \\
\hline Inokulum I1 (5\%) & $24,3^{\mathbf{c}}$ & $22,0^{\mathbf{b}}$ & $20,3^{\mathbf{a}}$ & 22,2 \\
\hline Inokulum I2 (10\%) & $35,6^{\mathbf{f}}$ & $33,6^{\mathbf{e}}$ & $32,0^{\mathbf{d}}$ & 33,7 \\
\hline Inokulum I3 (15\%) & $48,6^{\mathbf{h}}$ & $47,6^{\mathbf{h}}$ & $46,3^{\mathbf{g}}$ & 47,5 \\
\hline Rerata Kadar Serat (\%) & 36,2 & 35,4 & 32,8 & \\
\hline
\end{tabular}

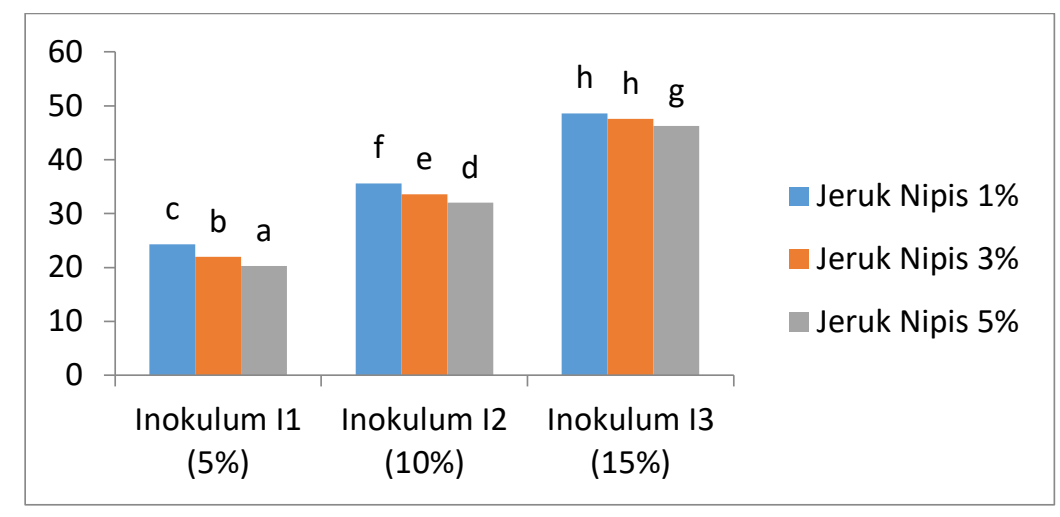

Gambar 4. Grafik kadar serat nata de soya dengan perlakuan penambahan konsentrasi inokulum dan jeruk nipis

Tabel 5. Tekstur nata de soya dengan perlakuan penambahan konsentrasi inokulum dan jeruk nipis

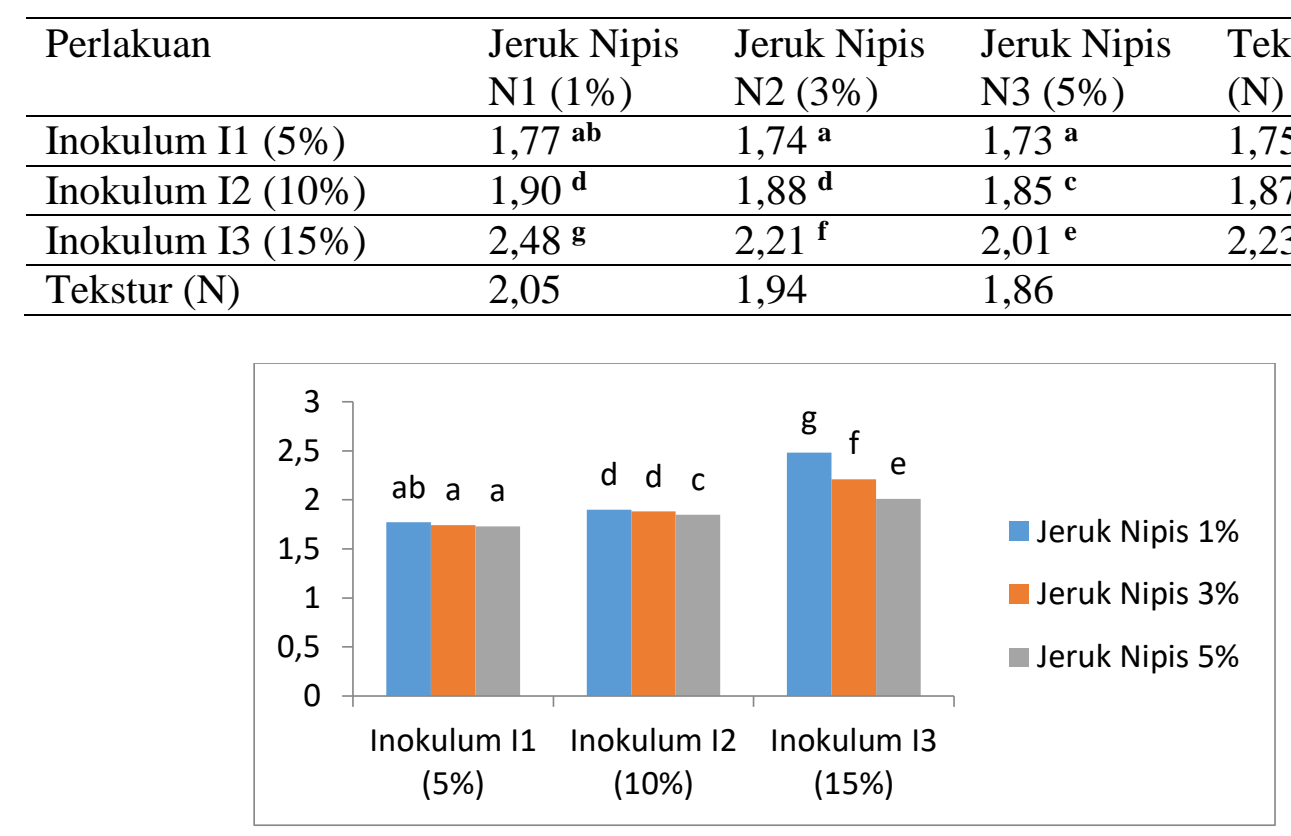

Gambar 5. Grafik tekstur nata de soya dengan perlakuan penambahan konsentrasi inokulum dan jeruk nipis 


\section{Kesimpulan}

Konsentrasi inokulum dengan penambahan jeruk nipis memberikan pengaruh yang nyata terhadap ketebalan, rendemen, kadar air dan serat, namun konsentasi inokulum 5\% dengan penambahan jeruk nipis 3\% dan 5\% tidak berpengaruh nyata terhadap tekstur nata de soya.

Konsentrasi inokulum $15 \%$ dan penambahan jeruk nipis $1 \%$ memberikan nilai terbaik dari semua perlakuan yaitu ketebalan 1,04 cm; rendemen 205,33 g;

\section{Daftar Pustaka}

Alviani, K.D., 2016, Pengaruh Konsentrasi Gula Kelapa dan Starter Acetobacter Xylinum Terhadap Kualitas Fisik dan Kimiawi Nata de Leri, Skripsi, Jurusan Biologi, Universitas Islam Negeri Maulana Malik Ibrahim, Malang.

Budiarti, R.S., 2008, Pengaruh Konsentrasi Starter Acetobacter xylinum Terhadap Ketebalan dan Rendemen Selulosa Nata de Soya, Jurnal Biospesies, 1(1), 19-24.

Effendi, D.S., Utami, 2006, Pengaruh Penggunaan Bahan Dasar Dan Jenis Gula Terhadap Tebal Lapisan dan Uji Organoleptik Nata, Program Kreativitas Mahasiswa. Jurusan Biologi, FPMIPA, IKIP PGRI, Madiun.

Haryadi, 2009, Pembuatan Nata de Pina Dari Kulit Nanas, Laporan Penelitian, Jurusan Teknik Kimia, Universitas Diponegoro, Semarang.

Hapsari, A.M., 2012, Limbah Produksi Tahu di Desa Somopuro, Kecamatan Jogonalan, Kabupaten Klaten, Jawa Tengah, Makalah Limbah Produksi Tahu di Desa Somopuro, Kecamatan Jogonalan, Kabupaten Klaten, Jawa Tengah. kadar air $86 \%$, kadar serat $48,6 \%$ dan tekstur $2,48 \mathrm{~N}$.

\section{Ucapan Terima Kasih}

Terima kasih penulis sampaikan kepada Universitas Widya Dharma Klaten, sebagai tempat kami melakukan penelitian ini, dan Kemenristek Dikti sebagai penyandang dana dalam penelitian ini, juga semua pihak yang telah banyak membantu dalam penyelesaian penelitian ini.

Hindersah, R., Hernanto, Y., Joy, B., Mulyani, O., 2011, Pemanfaatan limbah tahu dalam pengomposan sampah rumah tangga untuk meningkatkan kualitas mikrobiologi kompos, Agrinimal, 1(1), 15-21.

Azhari, M., 2014, Pemanfaatan Limbah Cair Tahu Menjadi Nata de Soya dengan Menggunakan Air Rebusan Kecambah Kacang Tanah dan Bakteri Acetobacter Xylinum, Tesis, Program Pascasarjana Universitas Sebelas Maret, Surakarta.

Heryawan, K., 2004, Pengaruh Konsentrasi Gula dan Lama Waktu Fermentasi Terhadap Mutu Nata de Pina, Skripsi, Jurusan Teknologi Hasil Pertanian, Unsiyah, Banda Aceh.

Iryandi, F. A., Hendrawan, F., Komar, N., 2014, Pengaruh Penambahan Air jeruk Nipis (Citrus aurantifolia) dan Lama Fermentasi Terhadap Karakteristik Nata de Soya, Jurnal Bioproses Komoditas Tropis, 1(1).

Khotimah, K., 2002, Pengaruh Ekstrak Jeruk Nipis (Citrus aurantifolia) dan Metode Pengolahan pada Kualitas Daging Broiler, Biotechnology Center UMM, Malang. 
Iryandi, dkk., 2014, Pengaruh Penambahan Air Jeruk Nipis (Citrus aurantifolia) dan Lama Fermentasi Terhadap Karakteristik Nata De Soya, Jurnal Bioproses Komoditas Tropis, 1(1).

Lauma, dkk., 2015, Uji Efektifitas Perasan Air Jeruk Nipis (Citrus aurantifolia S) Terhadap Pertumbuhan Bakteri Staphylococcus aureus Secara In Vitro, PHARMACON Jurnal Ilmiah Farmasi-UNSRAT, 4(4).

Lempang, M., 2006, Rendemen dan Kandungan Nutrisi Nata de Pina Yang Diolah Dari Nira Aren, Jurnal Teknologi Pangan, 24(2), 3-6.

Nainggolan, J., 2009, Kajian Pertumbuhan Bakteri Acetobacter sp Dalam Kombucha-Rosela Merah (Hibiscus sabdariffa) Pada Kadar Gula dan Fermentasi Yang Berbeda, Tesis, Universitas Sumatera Utara, Medan.

Nisa, F.C., dkk., 2001, Produksi Nata Dari Limbah Cair Tahu (Whey) : Kajian Penambahan Sukrosa Dan Ekstrak Kecambah, Jurnal Teknologi Pertanian, 2, 74-78.

Nisa, F.C., 2002, Penurunan Tingkat Pencemaran Limbah Cair (Whey) Tahu pada Produksi Nata de Soya (Kajian Waktu Inkubasi), Jurnal Teknologi Pertanian, 3(2), Universitas Brawijaya.

Pusat Penelitian IPB, 2005, Acetobacter xylinum, Laporan Hasil Penelitian, Institut Pertanian Bogor.
Rahman, 2004, Pengantar Teknologi Fermentasi, Arcan, Jakarta.

Saptarina, S., 2017, Pengaruh Variasi Konsentrasi Gula Jawa Terhadap Ketebalan, Warna, Aroma, Tekstur dan Rasa Nata de Tomato, Skripsi, Program Studi Pendidikan Biologi, Jurusan Pendidikan Matematika dan Ilmu Pengetahuan Alam. Fakultas Keguruan dan Ilmu Pendidikan, Universitas Sanata Dharma, Yogyakarta.

Saragih, Y.P., 2004, Membuat Nata De Coco, Puspa Swara, Jakarta.

Souisa, M.G., dkk., 2007, Pengaruh Acetobacter xylinum dan Ekstrak Kacang Hijau (Phaseolus Radiatus L) Terhadap Produksi Nata Dari Substrat Limbah Cair Tahu, Biota, ISSN 0853-8670.

Tamimi, A., Sumardi, H.S., Hendrawan, Y., 2015, Pengaruh Penambahan Sukrosa dan Urea Terhadap Karakteristik Nata de Soya Asam Nipis-In Press, Jurnal Bioproses Komoditas Tropis, Universitas Brawijaya, Malang.

Yani, M., M. Rahayuningsih, Purwoko, Suparno, D. Setyaningsih, 2000, Penuntun Praktikum Laboratorium Bioproses. 